\title{
Prediction of Punching Strength of Reinforced Concrete Footings by Finite Element Method
}

\author{
Faris R. Ahmed ${ }^{1, *}$, Kamaran K. Hamad ${ }^{2}$, Zahraa N. Rashied ${ }^{3}$ \\ ${ }^{1}$ Civil Engineering Department, Faculty of Engineering, Koya University, Erbil, Kurdistan Region, Iraq \\ ${ }^{2}$ Survey Engineering Department, Collage of Engineering, Salahaddin University, Erbil, Kurdistan Region, Iraq \\ ${ }^{3}$ Geotechnical Engineering Department, Faculty of Engineering, Koya University, Erbil, Kurdistan Region, Iraq \\ *Corresponding author: faris.rashied@koyauniversity.org
}

\begin{abstract}
This paper presents a nonlinear finite element modeling and analysis of the punching behaviour of reinforced concrete footings. The foundation system was modeled using ANSYS software. Several experimental tests were collected from literature to support the software outputs. The deflection in the footing's concrete has been studied, marking the cracking patterns under column, and computing the failure loads for each footing. The experiments results were compared with the finite element results obtained from the modeled footing. The results indicated that the punching behaviour obtained from the analytical model using ANSYS software give good agreement with the experimental data with conservative difference of about 10 percent. Also, results of column's punching shear capacity, using a number of codes of practice, were presented in this paper and compared with both experimental and the finite element results.
\end{abstract}

Keywords: punching, shear stresses, comparative analysis, footings, finite element analysis, ANSYS

Cite This Article: Faris R. Ahmed, Kamaran K. Hamad, and Zahraa N. Rashied, "Punching, Shear stresses, Comparative analysis, Footings, Finite element analysis, ANSYS." American Journal of Civil Engineering and Architecture, vol. 5, no. 1 (2017): 8-16. doi: 10.12691/ajcea-5-1-2.

\section{Introduction}

One of the undesirable structural failure modes in buildings is the brittle punching shear failure of footings. Unfortunately, the number of experiments of footings punching on real soil is too small to formulate general conclusions. Deficit of experimental results for column footings leads to the use of finite element analysis models since a more detailed parametric study can be conducted to determine the influence of the parameters that are introduced in calculating the footing punching capacity.

Lee et. al. (2014) [9] used nonlinear finite element (FE) analysis to study the punching failure behavior of the footing. Series of experimental tests were performed by inserting steel funnel shaped to act as punching preventer (Punching Shear Preventers, PSP). The objective of the new method was to increase the punching capacity and the ductility of the footing. Five large scale footings were tested with the same size and reinforcement. The size effect, thickness, and location of PSP had been investigated. It was concluded that the FE analysis is capable of verifying the test results. The results and the proposed design recommendations were compared with ACI Code prediction and showed underestimation of the footing capacity with these punching preventers.

Vacev et. al. (2015) [13] made one experimental test sample of dimensions $(850 \times 850 \times 125) \mathrm{mm}$ of isolated reinforced concrete (RC) column footings rested on sub-grade soil and loaded until failure. The aim of the study was to determine the behavior of footing's punching failure and comparing it with the result obtained from finite element analysis using ANSYS software. The researcher discussed the method of choosing the criterion of determining the failure load by FE. They suggested several methods such as the time when equilibrium of the internal forces is no longer valid due to the excessive deformations, by recording the vertical sudden displacement of the column top, or by observing the reinforcement strain for the column and footing and recording the sudden strain. No obvious statement was stated about which criteria was selected by the authors to determine the failure load, but it seems that it was the one which gives the lowest value.

\section{Previous Experimental Works on Footing Punching}

According to literature, relatively few punching tests for column footings resting on real bedding have been performed. The bedding natural was simulated in some of these tests by steel springs [11], by a set of small jacks, or by line loads which produced the same effect as the load exerted by a uniformly reactive soil [5]. The punching tests on real soil were practically implemented by Hegger et. al. (2006) [6] in a sandbox and by a real soil by Folić et. al. (2013) [4]. The geometric characteristics, number of tested footings, and supports used are presented in Table 1. 
Table 1. Summary of some previous column-footing experiments

\begin{tabular}{|c|c|c|c|c|c|}
\hline \multirow{2}{*}{ Author / Year } & Support type & No. of tested footings & \multicolumn{3}{|c|}{ Geometry of footing } \\
\cline { 3 - 6 } & & & Shape & $\begin{array}{c}\text { Dimension } \\
\text { mm }\end{array}$ & $\begin{array}{c}\text { Effective depth } \\
\text { mm }\end{array}$ \\
\hline Folić et. al. (2013) [4] & Gravel Surface & 6 & square & 850 & 100 to 175 \\
\hline Hegger et. al (2009) [7] & Sandbox and column stub & 17 & square & 1200 to 1800 & 250 to 470 \\
\hline Hegger et. al (2006) [6] & Sand box & 5 & square & 900 & 150 to 250 \\
\hline Timm (2003) [12] & Line & 10 & square & 760 to 1080 & 172 to 246 \\
\hline Hallgren et. al. (1998) [5] & Line \& surface & 14 & square and circular & 850 to 960 & 273 to 278 \\
\hline $\begin{array}{c}\text { Dieterle \& Rostasy (1987) } \\
\text { (Cited by [4]) }\end{array}$ & Flat & 13 & square & 1500 to 3000 & 320 to 800 \\
\hline $\begin{array}{c}\text { Kordina \& Nölting (1981) } \\
\text { (Cited by [4]) }\end{array}$ & Flat & 17 & rectangular & 1500 to 3000 & 193 to 740 \\
\hline Rivkin (1967) [10] & Flat/clay \& sand & 6 & square & 650 and 1000 & 120 \\
\hline Richart (1948) (cited by [4]) & Springs & 149 & square and circular & 610 to 3000 & 200 to 740 \\
\hline Talbot (1913) [11] & Springs & 20 & square & 1520 & 250 \\
\hline
\end{tabular}

Table 2. Experimental data of previous column-footing experiments

\begin{tabular}{|c|c|c|c|c|c|c|c|c|c|c|c|c|c|c|c|}
\hline Ref. & Foot. ID & $\begin{array}{c}\mathrm{h} \\
\mathrm{mm}\end{array}$ & $\begin{array}{c}\mathrm{d} \\
\mathrm{mm}\end{array}$ & $\begin{array}{c}\mathrm{c} \\
\mathrm{mm}\end{array}$ & $\begin{array}{c}b \\
\mathrm{~mm}\end{array}$ & $\begin{array}{c}a \\
\mathrm{~mm}\end{array}$ & $a / d$ & $\begin{array}{c}\mathrm{f}_{\mathrm{c}} \\
\mathrm{MPa}\end{array}$ & $\begin{array}{c}E_{c} \\
\mathrm{MPa}\end{array}$ & $\begin{array}{l}\rho \\
\%\end{array}$ & $\begin{array}{l}\rho^{\prime} \\
\%\end{array}$ & $\begin{array}{c}\mathrm{f}_{\mathrm{y}} \\
\mathrm{MPa}\end{array}$ & $\begin{array}{c}A_{v} \\
\mathrm{~cm}^{2}\end{array}$ & $\begin{array}{c}S \\
\mathrm{~mm}\end{array}$ & $\begin{array}{c}\text { Vtest } \\
\mathrm{kN}\end{array}$ \\
\hline \multirow{6}{*}{ 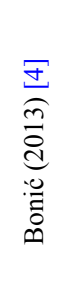 } & TI & 200 & 175 & 175 & 850 & 337.5 & 1.93 & 32.6 & 27,726 & 0.4 & 0 & 570 & - & - & 906 \\
\hline & TII & 150 & 125 & 175 & 850 & 337.5 & 2.70 & 32.6 & 27,726 & 0.4 & 0 & 570 & - & - & 1050 \\
\hline & TIV & 125 & 100 & 175 & 850 & 337.5 & 3.38 & 18.1 & 20,634 & 0.4 & 0 & 570 & - & - & 430 \\
\hline & TV & 175 & 150 & 175 & 850 & 337.5 & 2.25 & 18.1 & 20,634 & 0.4 & 0 & 570 & - & - & 656 \\
\hline & TVI & 150 & 125 & 175 & 850 & 337.5 & 2.70 & 16.4 & 19,659 & 0.4 & 0 & 570 & - & - & 451 \\
\hline & TVII & 150 & 125 & 175 & 850 & 337.5 & 2.70 & 8.5 & 14,155 & 0.4 & 0 & 570 & - & - & 440 \\
\hline \multirow{5}{*}{ 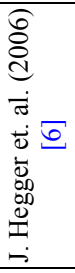 } & DF1 & 200 & 150 & 150 & 900 & 375 & 2.5 & 20.2 & 24000 & 1.03 & 0 & 552 & - & - & 551 \\
\hline & DF2 & 200 & 150 & 150 & 900 & 375 & 2.5 & 22 & 22600 & 1.03 & 0 & 552 & - & - & 530 \\
\hline & DF3 & 200 & 150 & 150 & 900 & 375 & 2.5 & 30.7 & 25800 & 1.03 & 0.33 & 552 & 40.7 & 75 & 1197 \\
\hline & DF4 & 300 & 250 & 150 & 900 & 375 & 1.5 & 24.5 & 24000 & 0.62 & 0 & 552 & - & - & 1251 \\
\hline & DF5 & 300 & 250 & 175 & 900 & 362.5 & 1.45 & 17.6 & 23300 & 0.73 & 0 & 515 & - & - & 1130 \\
\hline \multirow{17}{*}{ 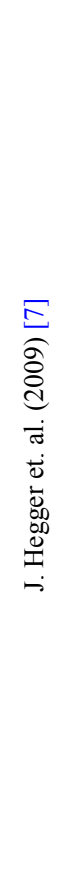 } & DF6 & 450 & 395 & 200 & 1200 & 500 & 1.27 & 19 & 23,450 & 0.87 & 0 & 552 & - & - & 2836 \\
\hline & DF7 & 450 & 395 & 200 & 1400 & 600 & 1.52 & 20.9 & 25,067 & 0.87 & 0 & 552 & - & - & 2569 \\
\hline & DF8 & 300 & 250 & 200 & 1200 & 500 & 2.0 & 22.5 & 24,850 & 0.88 & 0 & 552 & - & - & 1203 \\
\hline & DF9 & 300 & 250 & 200 & 1200 & 500 & 2.0 & 20.8 & 24,700 & 0.89 & 0.49 & 552 & 28.4 & 90 & 2784 \\
\hline & DF10 & 300 & 250 & 200 & 1200 & 500 & 2.0 & 38.1 & 29,500 & 0.91 & 0 & 552 & - & - & 1638 \\
\hline & DF11 & 450 & 395 & 200 & 1200 & 500 & 1.27 & 21.4 & 22,000 & 0.87 & 0 & 552 & - & - & 2813 \\
\hline & DF12 & 450 & 395 & 200 & 1400 & 600 & 1.52 & 21.2 & 23,700 & 0.88 & 0 & 552 & - & - & 2208 \\
\hline & DF13 & 450 & 395 & 200 & 1800 & 800 & 2.03 & 21.1 & 20,100 & 0.87 & 0 & 552 & - & - & 1839 \\
\hline & DF14 & 350 & 295 & 200 & 1400 & 600 & 2.03 & 21.2 & 23,700 & 0.88 & 0 & 552 & - & - & 1478 \\
\hline & DF15 & 530 & 470 & 200 & 1400 & 600 & 1.28 & 21.7 & 22,500 & 0.85 & 0 & 552 & - & - & 2750 \\
\hline & DF16 & 450 & 395 & 200 & 1200 & 500 & 1.27 & 20 & 20,900 & 0.87 & 0.31 & 552 & 45.2 & 190 & 3680 \\
\hline & DF17 & 450 & 395 & 200 & 1400 & 600 & 1.52 & 20.8 & 22,000 & 0.87 & 0.31 & 552 & 45.2 & 190 & 3619 \\
\hline & DF18 & 450 & 395 & 200 & 1800 & 800 & 2.03 & 21.7 & 22,500 & 0.87 & 0.31 & 552 & 45.2 & 190 & 3361 \\
\hline & DF19 & 450 & 395 & 200 & 1200 & 500 & 1.27 & 21.8 & 21,900 & 0.87 & 0 & 552 & - & - & 2790 \\
\hline & DF20 & 450 & 395 & 200 & 1200 & 500 & 1.27 & 35.7 & 27,400 & 0.87 & 0 & 552 & - & - & 3037 \\
\hline & DF21 & 450 & 395 & 200 & 1400 & 600 & 1.52 & 36.3 & 26,800 & 0.87 & 0 & 552 & - & - & 2860 \\
\hline & DF22 & 450 & 395 & 200 & 1800 & 800 & 2.03 & 36.4 & 26,200 & 0.87 & 0 & 552 & - & - & 2405 \\
\hline
\end{tabular}

Note: $\mathrm{h}$ is overall footing depth; $\mathrm{d}$ is effective depth; $\mathrm{c}$ is square column dimension; $\mathrm{b}$ is footing dimension; $\mathrm{a}$ is footing dimension measured from face of column; $\mathrm{fc}^{\prime}$ is cylinder concrete compression strength; $E_{\mathrm{c}}$ is concrete Young's Modulus; $\rho$ is ratio of flexural reinf; $\rho$ ' is ratio of compression reinf: $A_{\mathrm{v}}$ is area of shear reinf.; $\mathrm{s}$ is spacing of stirrups; and $\mathrm{V}_{\text {test }}$ is the ultimate failure load. 
Hegger et. al. (2006) [6] tested five $900 \times 900 \mathrm{~mm}$ reinforced concrete footings (DF1 to DF5) with realistic boundary conditions and designed to fail in punching. Full details of the tested footings are given in Table 2. The square column stubs were cast monolithically at the center of the slabs. The footings DF4 and DF5 were designed to investigate the effect of small shear slenderness $(\mathrm{a} / \mathrm{d})$ on the punching behavior. Although specimen DF3 had shear reinforcement, but this is out of the scope of this work and it will be discarded.

The specimens were tested in a sandbox and their dimensions were chosen to fit into it. They developed a design model for the punching strength of footings taking into consideration the soil-structure interaction. The work results showed that the failure angle is steeper than observed in punching tests on flat slabs, and the shear slenderness considerably affects the punching shear capacity. Furthermore, the sand density does not affect the distribution of stresses below the footing, i.e. considering a uniform stress distribution gives sufficient safety against punching. The derived model was based on BS81101:1997 [2] provisions.

Few years later and in order to supplement their previous work, Hegger et. al. (2009) [7] completed their works [4] and tested additional 17 reinforced concrete footings (DF6 to DF22) to study the punching shear behavior. Several (a/d) and concrete compressive strength were taken. The tests were divided into two series, (DF6 to DF10) were realistically supported on sand. The second one (DF11 to DF22) were inverted upside down so that it supported on the column stub and a load applied on footing via 16 Polytetrafluoroethylene (PTFE) bearings connected to steel beams to simulate the case of uniformly distribution.

The experimental investigations proved the previous conclusion that the angle of the shear crack was steeper in specimens on compact footings than observed in tests on more slender slabs. Furthermore, the $(\mathrm{a} / \mathrm{d})$ significantly affects the punching shear capacity since more loads will be distributed out of the punching failure cone. Based on the test results, the ACI and Eurocode- 2 provisions were reviewed and improvements were proposed. The experimental program and its implementation are described in Table 2.

The schematic of the experimental setup of Folic et. al. (2013) [4] consisting of a test frame, six test specimens, hydraulic jack, and prepared sub-grade. The frame is placed at the bottom of the footing pit measuring $4 \times 5 \mathrm{~m}$ in plan with $3 \mathrm{~m}$ depth. Gravel layers are compacted by vibrator at the bottom of testing steel frame. The gravel layers and the sub-soil compacted so that the modulus of compressibility was chosen to be about 40 to $70 \mathrm{MPa}$, which represent the normal compaction of the subsoil.

The adopted footing dimensions were $850 \times 850 \mathrm{~mm}$ in plan, and they correspond to experiments made by Hegger et al. (2006) [6] for the sake of result comparison possibilities, and also to be within the capacity of the available test equipment (approximately $1000 \mathrm{kN}$ ). Foundations TIII and TVIII did not fail since their punching capacity was higher than the capacity of the testing machine. The dimensions and characteristics of the footing are given in Table 2.

They concluded that the punching strength is mostly related to the floor structures, and less to the footings under columns. The results obtained were compared with the predicted results based on various codes/regulations and showed that the punching shear capacity values based on these codes are significantly underestimated.

\section{The Finite Element Model}

All material models used for simulate the material properties of the specimens to the computer program are given in this section. ANSYS 15 finite element program is used for analysis, and the material properties of concrete, reinforcement, soil, and pads are defined to feed the software to complete footing modeling.

\subsection{Concrete}

The eight nodded solid element, SOLID65, is used for the $3 \mathrm{D}$ modeling of solids with and without reinforcing bars since it has rebar capability for modeling reinforcement and its behavior. The element is able to crack in tension and crush in compression in three orthogonal directions, and capable of plastic deformation. The geometry and other specifications for this element are specified in the software technical specification. Three types of cracking in SOLID65 are possible which are labeled 'first', 'second' and 'third' according to their occurrence order and can be visualized based on these labels. The element features are not including calculating the crack width, so cracks existence does not mean that these cracks are visible. In this study, crack profiles with 'second' cracks are more consistent with the experimental cracks than the 'first' and 'third'.

\subsection{Reinforcement}

The rebars used in this work are smeared within the SOLID65 elements, and then the reinforcement defined using the real constants of SOLID65 element. This method needs more efforts in modeling than discrete it with the LINK8 element. The required steel properties to feel the software include density, modulus of elasticity, and Poisson's ratio and they are shown in Table 2 and Table 3.

\subsection{Modeling of Bearings Pad}

SOLID65 is also used to represent the PTFE bearing pads. They were modeled as a linear isotropic material with properties as shown in Table 3.

\subsection{Modeling of Soil}

The soil was modeled as an isotropic material with the basis of the Drucker-Prager's elastic-perfectly plastic material criteria. The models were developed using 3D SOLID65 Element. In order to use this material model, it is necessary to define the cohesion (C), and angle of internal friction $(\varphi)$ which are given in the original references, with modulus of elasticity and Poisson's ratio. For sand or gravel soils (i.e. cohesion $\mathrm{C}=0$ ), implies that the material does not have any uniaxial compressive or tensile strength. The material, therefore, has to be iterated 
into a stable position. This leads to convergence difficulties, so it is advised to use an adequately small value instead of zero for the cohesion while using the Mohr-Coulomb (LAW $=1$ ) yield conditions [ANSYS, 2015].

\subsection{Modeling Interaction Contact}

In ANSYS, several possible ways to represent the interaction contacts are possible. In this research Node-toSurface model is used to represent the contact between footing and pads/soil elements. CONTA175 element is used here, which has a great ability to simulate large sliding and deformation. Contact occurs when the element surface penetrates one of the target segment elements (TARGE170) on a specified target surface. The nonlinear contact elements CONTA175 were added to the surface of the footing, while TARGE170 elements were added to the bearing pad and soil surfaces. [ANSYS, 2015].

\subsection{Boundary Conditions}

Although the model was symmetric, the whole models were simulated. The nodes of the bearing pads in the lowest plane were constrained in all degrees of freedom (DOF); the left and right planes were left free without any constraints, so that it could move in all directions. For the case of soil, all nodes located on all lateral faces of soil block were released in vertical direction while in other direction were constrained. Nodes located on bottom face of soil block were constrained in all directions. See Figure 1.

Table 3. Material properties for ANSYS model

\begin{tabular}{|c|c|c|c|}
\hline Material & $\begin{array}{c}\text { Density } \\
\left(\mathrm{kg} / \mathrm{m}^{3}\right)\end{array}$ & $\begin{array}{c}\text { Modulus of elasticity } \\
(\mathrm{MPa})\end{array}$ & see Table 2 \\
\hline Concrete & 2400 & 200,000 & 0.22 \\
\hline Steel & 7850 & 1440 & 0.3 \\
\hline Bearings pads & 2150 & based on soil type $[8]$ & 0.415 \\
\hline Soil & 1700 & based on soil type [8] \\
\hline
\end{tabular}

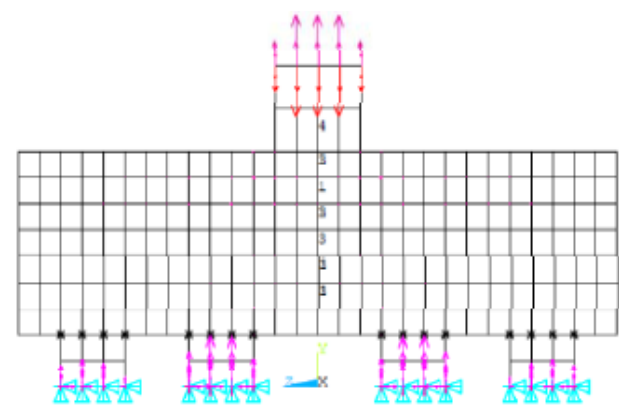

(a) For footings supported on pads

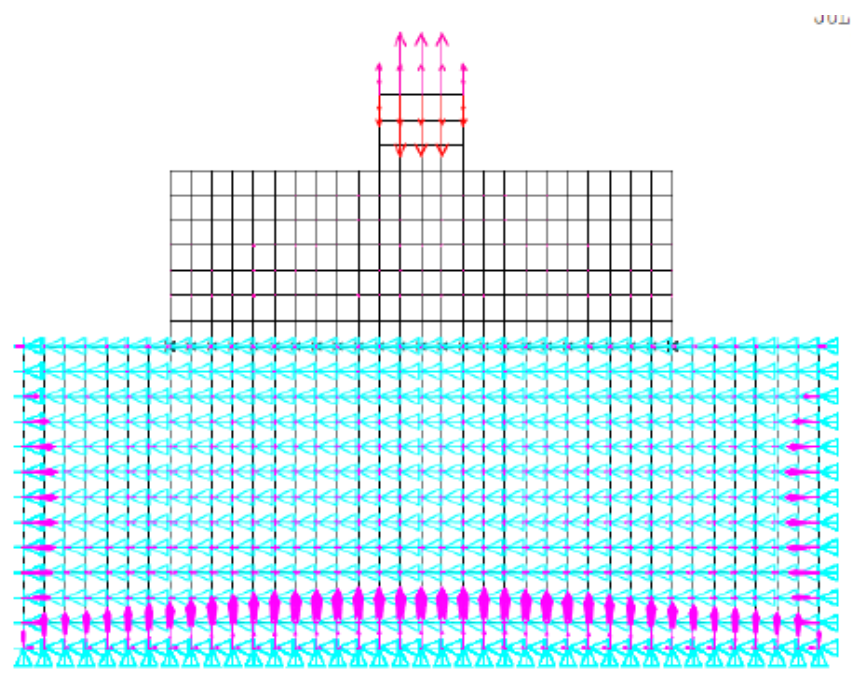

(b) End faces for footings supported on soil

Figure 1. ANSYS Loads and boundary conditions

\subsection{Loads and Load Stepping}

In this work, the total applied load was divided into a series of load steps (increments). The ANSYS software controls the size of these steps whether maximum or minimum load step size is required according to the previous solution history and the convergence behavior whether it is smooth or abrupt. The total numerical applied load was that from the experiment increased by $10 \%$.

\section{Discussions of Results}

The aims of this study were to show:

(1) To check the applicability of ANSYS software for analyzing and predicting the crack patterns and failure loads of RC footings;

(2) To show the entire phases of the FE model behavior from initial cracking until failure.

\subsection{Load Deflection Curves}

A number of experimental deflection curves carried out by Hegger et. al. (2009) [7] with the corresponding ANSYS load-deflection curves obtained for the footings are illustrated in Figure 2. The curves, in general, showed a good agreement in FE analysis with the test results. It's been noticed that deflection by the ANSYS is slightly stiffer than the actual footings because full bond between concrete and reinforcement is assumed (no slip) in the finite element analyses, but for the actual footings slip occurs anyway. 

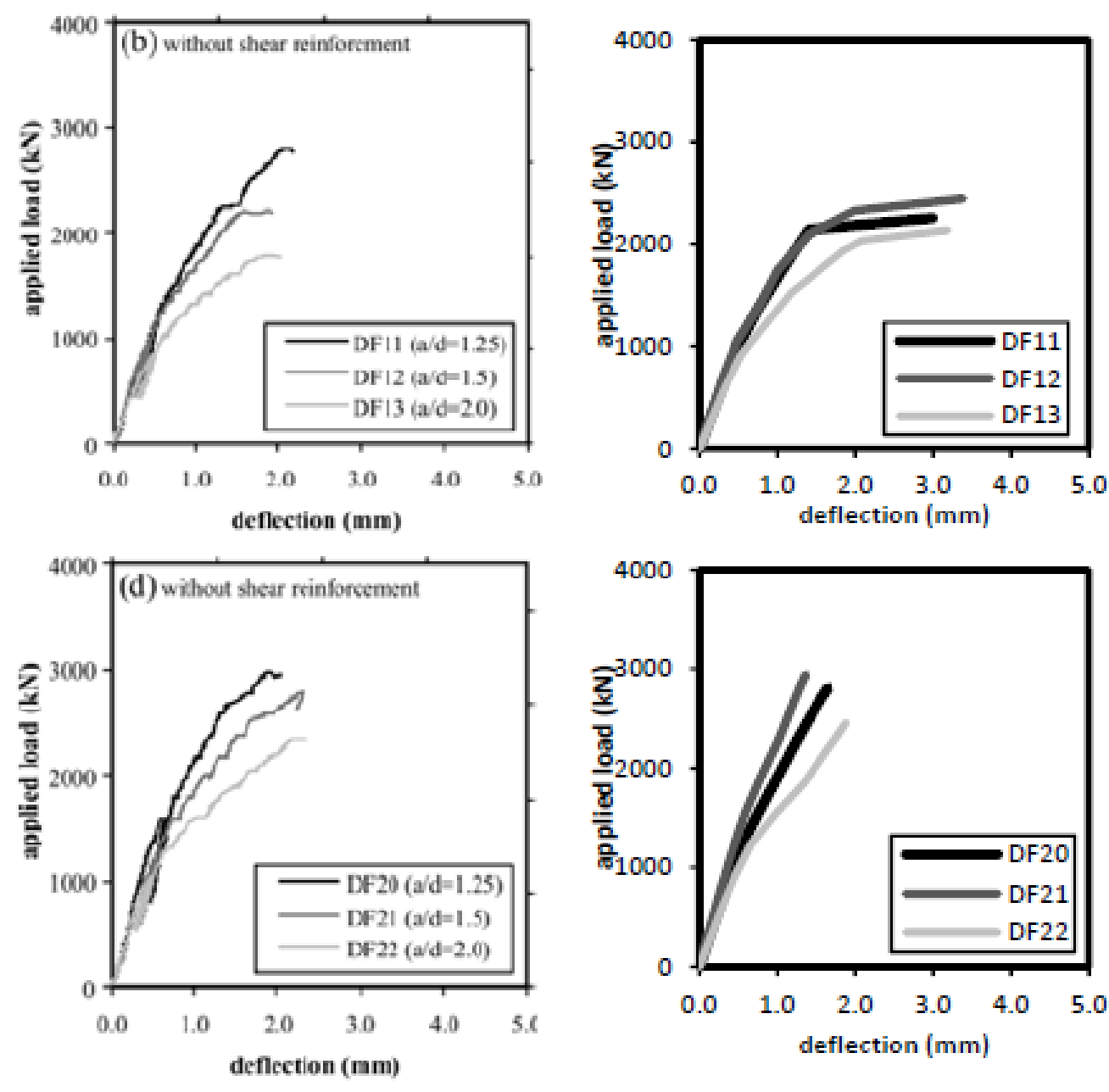

(a)

(b)

Figure 2. Load-deflection curves obtained for the footings; (a) Original test, (b) Deflection by FE (ANSYS)

\subsection{Failure Load}

Results showed that the failure load obtained from the FE analysis is slightly smaller (conservative) than the experimental load. The final loads for the finite element models are the last applied load step before the solution diverges due to numerous cracks and large deflections, see Figure 3, (i.e. as example, by comparing Figure 3 with Figure 2(b) above, the deflection is increased dramatically in one load step!).

Table 4 shows comparison between the ultimate loads of the experimental footings and the final loads from the FE models.

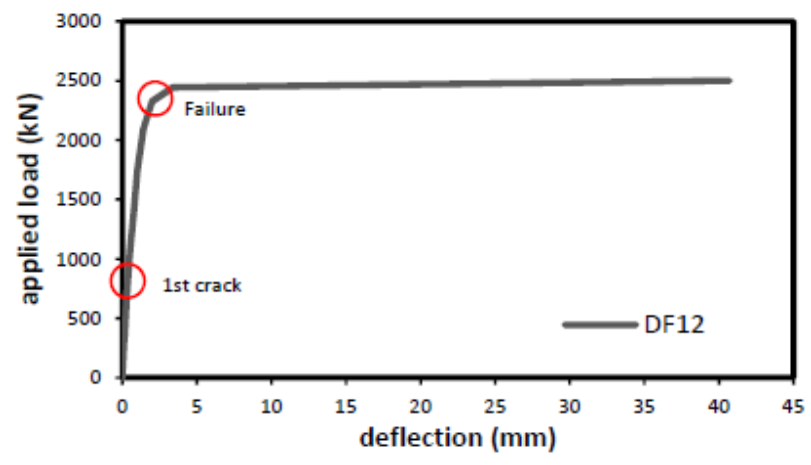

Figure 3. Large deflection when reaching the ultimate load

\subsection{Cracks Pattern}

The ANSYS program save the cracks pattern for each load step, displaying circles at cracks locations or crushing in the concrete elements. Cracking is displayed as a small circle in the crack plane, while crushing is shown as an octahedron outline. The 'first' crack at integration point is shown with a red circle outline, the 'second' crack with a green outline, and the 'third' crack with a blue outline [ANSYS, Inc 2015].

Figure 4 shows crack patterns progressing developed for some models at the last loading step. It is clear that, in general, the generated cracks have almost the same crack shape and angle corresponding to the experimental specimens at failure stage.

\subsubsection{Deflection and Stress Comparison at First Cracking}

The cracking patterns in the footings can be obtained using the Crack/Crushing plot option in ANSYS. Vector Mode plots must be turned on to view the cracking in the model. The initial cracking of the footing DF12 (as example) in the FE model corresponds to a load of $800 \mathrm{kN}$ (which is represent about $34 \%$ of the ultimate punching capacity of footing) and induces stress beyond the modulus of rupture of concrete $(3.14 \mathrm{MPa})$ as shown in Table 2 . 


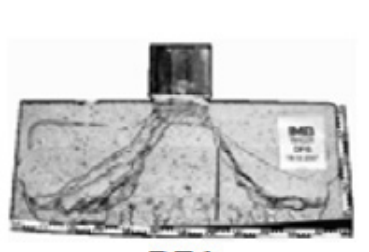

DF6

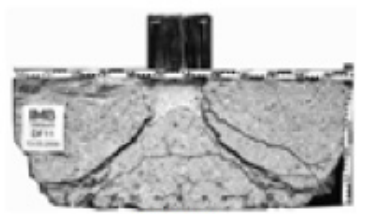

DF11

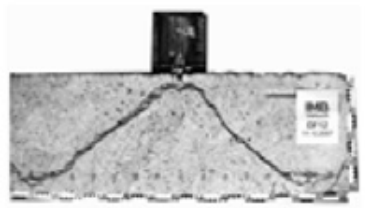

DF12

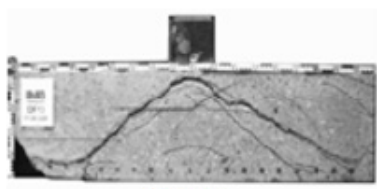

DF13

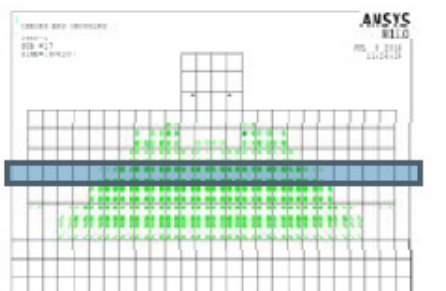

ANSYS
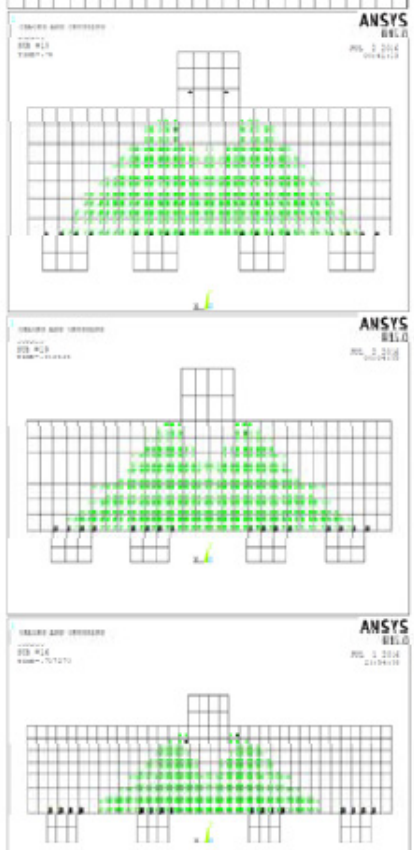

Figure 4. Crack patterns for some models with the corresponding real test
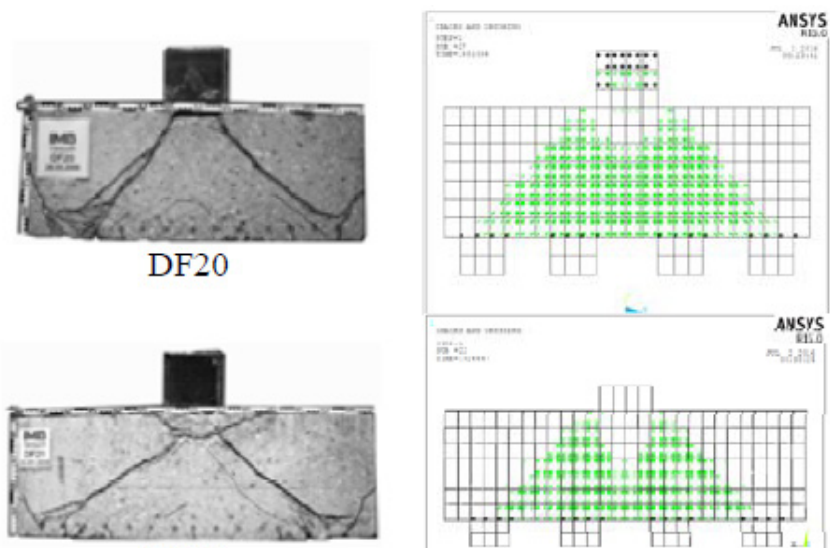

DF21

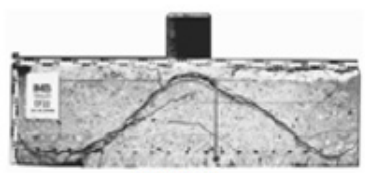

DF22
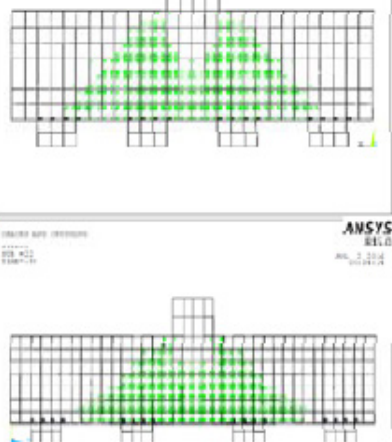

Table 4. Comparison of ultimate normal force in column

\begin{tabular}{|c|c|c|c|c|c|c|c|c|c|c|c|c|c|c|c|}
\hline \multirow[b]{2}{*}{ Ref. } & \multirow{2}{*}{$\begin{array}{l}\text { Footing } \\
\text { ID }\end{array}$} & d & $\mathrm{c}$ & $b$ & fc & $\square$ & Vtest & VFEM & VACI & VBS & $\begin{array}{c}V E C- \\
2\end{array}$ & \multirow{2}{*}{$\frac{V_{F E M}}{V_{\text {test }}}$} & \multirow{2}{*}{$\frac{V_{A C I}}{V_{\text {test }}}$} & \multirow{2}{*}{$\frac{V_{B S}}{V_{\text {test }}}$} & \multirow{2}{*}{$\frac{V_{U C-2}}{V_{\text {test }}}$} \\
\hline & & $\mathrm{mm}$ & $\mathrm{mm}$ & $\mathrm{mm}$ & $\mathrm{MPa}$ & $\%$ & $\mathrm{kN}$ & $\mathrm{kN}$ & $\mathrm{kN}$ & $\mathrm{kN}$ & $\mathrm{kN}$ & & & & \\
\hline \multirow{6}{*}{ 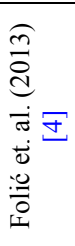 } & TI & 175 & 175 & 850 & 32.6 & $0.4 \%$ & 906 & 850 & 462 & 324 & 315 & 0.94 & 0.51 & 0.36 & 0.35 \\
\hline & TII & 125 & 175 & 850 & 32.6 & $0.4 \%$ & 1050 & -- & 286 & 198 & 176 & -- & 0.27 & 0.19 & 0.17 \\
\hline & TIV & 100 & 175 & 850 & 18.1 & $0.4 \%$ & 430 & 292 & 156 & 119 & 104 & 0.68 & 0.36 & 0.28 & 0.24 \\
\hline & $\mathrm{TV}$ & 150 & 175 & 850 & 18.1 & $0.4 \%$ & 656 & 542 & 276 & 211 & 207 & 0.83 & 0.42 & 0.32 & 0.32 \\
\hline & TVI & 125 & 175 & 850 & 16.4 & $0.4 \%$ & 451 & 400 & 202 & 157 & 148 & 0.89 & 0.45 & 0.35 & 0.33 \\
\hline & TVII & 125 & 175 & 850 & 8.5 & $0.4 \%$ & 440 & 280 & 146 & 126 & 126 & 0.64 & 0.33 & 0.29 & 0.29 \\
\hline \multirow{4}{*}{ 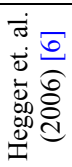 } & DF1 & 150 & 150 & 900 & 20.2 & $1.03 \%$ & 551 & 518 & 270 & 289 & 262 & 0.94 & 0.49 & 0.52 & 0.48 \\
\hline & DF2 & 150 & 150 & 900 & 22 & $1.03 \%$ & 530 & 493 & 281 & 297 & 269 & 0.93 & 0.53 & 0.56 & 0.51 \\
\hline & DF4 & 250 & 150 & 900 & 24.5 & $0.62 \%$ & 1251 & 1012 & 660 & 572 & 580 & 0.81 & 0.53 & 0.46 & 0.46 \\
\hline & DF5 & 250 & 175 & 900 & 17.6 & $0.73 \%$ & 1130 & 940 & 594 & 556 & 570 & 0.83 & 0.53 & 0.49 & 0.50 \\
\hline \multirow{13}{*}{ 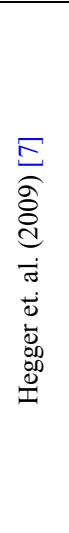 } & DF6 & 395 & 200 & 1200 & 19 & $0.87 \%$ & 2836 & 1919 & 1366 & 1276 & 1332 & 0.68 & 0.48 & 0.45 & 0.47 \\
\hline & DF7 & 395 & 200 & 1400 & 20.9 & $0.87 \%$ & 2569 & -- & 1433 & 1317 & 1366 & -- & 0.56 & 0.51 & 0.53 \\
\hline & DF8 & 250 & 200 & 1200 & 22.5 & $0.88 \%$ & 1203 & 1210 & 712 & 660 & 655 & 1.01 & 0.59 & 0.55 & 0.54 \\
\hline & DF10 & 250 & 200 & 1200 & 38.1 & $0.91 \%$ & 1638 & 1637 & 926 & 795 & 763 & 1.00 & 0.57 & 0.49 & 0.47 \\
\hline & DF11 & 395 & 200 & 1200 & 21.4 & $0.87 \%$ & 2813 & 2253 & 1450 & 1328 & 1374 & 0.80 & 0.52 & 0.47 & 0.49 \\
\hline & DF12 & 395 & 200 & 1400 & 21.2 & $0.88 \%$ & 2208 & 2327 & 1443 & 1328 & 1375 & 1.05 & 0.65 & 0.60 & 0.62 \\
\hline & DF13 & 395 & 200 & 1800 & 21.1 & $0.87 \%$ & 1839 & 1884 & 1439 & 1321 & 1369 & 1.02 & 0.78 & 0.72 & 0.74 \\
\hline & DF14 & 295 & 200 & 1400 & 21.2 & $0.88 \%$ & 1478 & 1525 & 896 & 836 & 844 & 1.03 & 0.61 & 0.57 & 0.57 \\
\hline & DF15 & 470 & 200 & 1400 & 21.7 & $0.85 \%$ & 2750 & 3010 & 1956 & 1753 & 1846 & 1.09 & 0.71 & 0.64 & 0.67 \\
\hline & DF19 & 395 & 200 & 1200 & 21.8 & $0.87 \%$ & 2790 & -- & 1463 & 1336 & 1381 & -- & 0.52 & 0.48 & 0.49 \\
\hline & DF20 & 395 & 200 & 1200 & 35.7 & $0.87 \%$ & 3037 & 2814 & 1872 & 1574 & 1574 & 0.93 & 0.62 & 0.52 & 0.52 \\
\hline & DF21 & 395 & 200 & 1400 & 36.3 & $0.87 \%$ & 2860 & 2880 & 1888 & 1583 & 1582 & 1.01 & 0.66 & 0.55 & 0.55 \\
\hline & DF22 & 395 & 200 & 1800 & 36.4 & $0.87 \%$ & 2405 & 2407 & 1891 & 1585 & 1583 & 1.00 & 0.79 & 0.66 & 0.66 \\
\hline & & & & & & & & & & & Ave. & 0.90 & 0.542 & 0.479 & 0.477 \\
\hline
\end{tabular}


The stress increases up to $3.24 \mathrm{MPa}$ at the centerline when the first crack occurs. The first crack can be seen in Figure 5, which is a flexural crack with maximum deflection of $0.356 \mathrm{~mm}$.

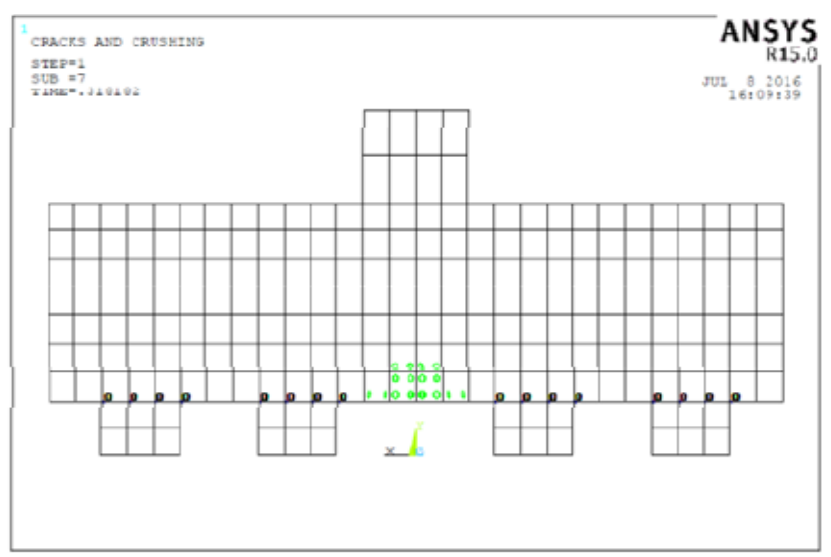

Figure 5. First concrete crack at $800 \mathrm{kN}$ for DF12

\subsubsection{Behavior after First Crack}

In the non-linear region of the response, subsequent cracking occurs as more loads are applied. Cracking increases in the region, and the footing starts cracking out at a load of $1,150 \mathrm{kN}$. Significant flexural cracking occurs in the footing at $1,500 \mathrm{kN}$. Also, diagonal tension cracks are starting to appear in the model. This cracking can be seen in Figure 6 and Figure 7.

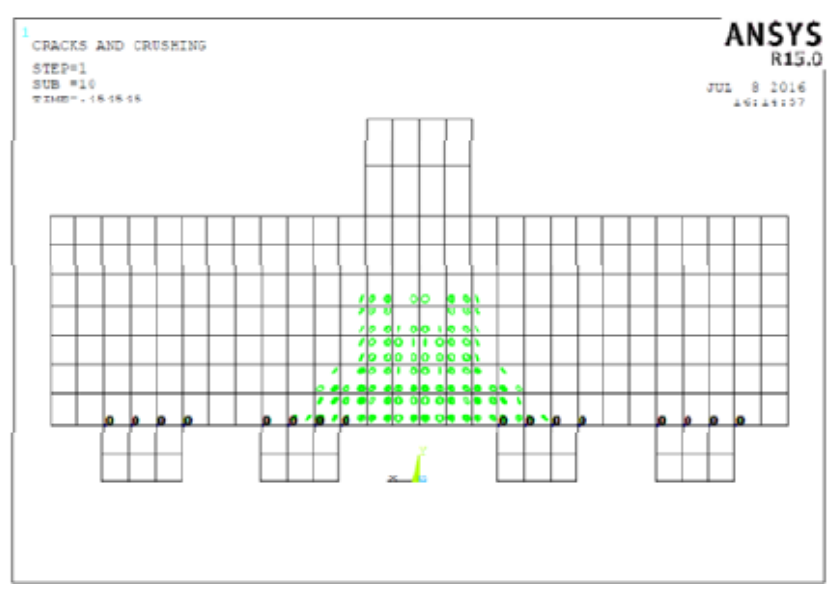

Figure 6. Cracking at $1,150 \mathrm{kN}$ for $\mathrm{DF} 12$

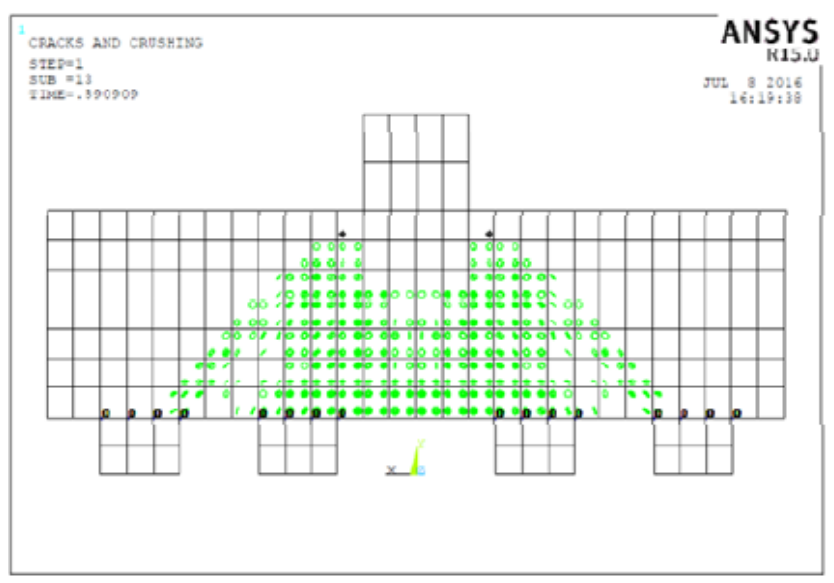

Figure 7. Increased cracking after yielding of reinforcement at $1,500 \mathrm{kN}$ for DF12

\subsubsection{Reinforcement Yielding and Beyond It}

Yielding of steel reinforcement occurs when a force of $1,500 \mathrm{kN}$ is applied, see Figure 7. At this point in the response, the displacements of the footing begin to increase at a higher rate as more loads are applied. The cracked moment of inertia, yielding steel and nonlinear concrete material, now defines the flexural rigidity of the member. Larger deflections occur at the center and the ability of the footing to distribute load throughout the cross section decreased greatly.

Figure 8 shows successive cracking of the concrete footing after yielding of the steel occurs. At 2,200 kN, the footing has increasing flexural cracks, and diagonal tension (shear) cracks. Cracking reached the top face, failure is soon to follow.

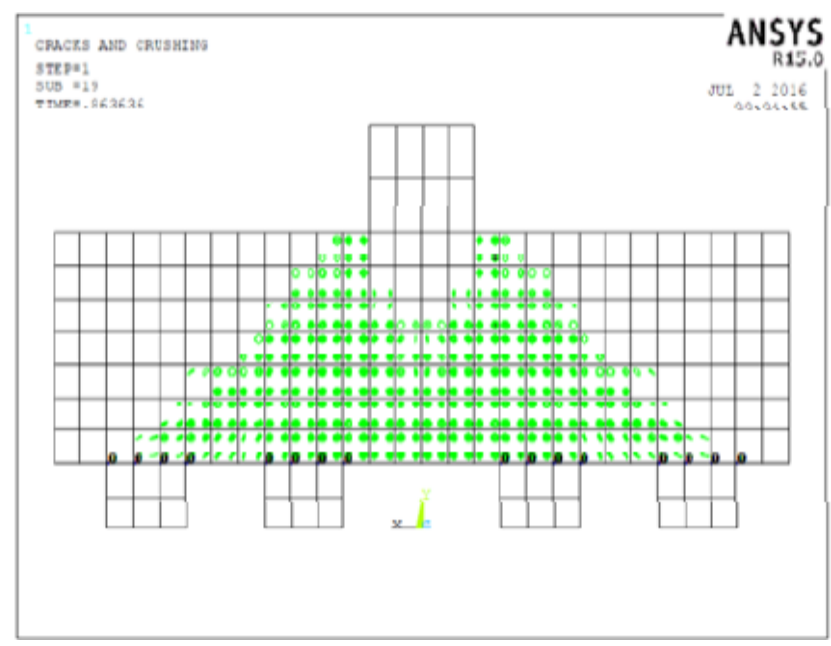

Figure 8. Failure of the concrete footing at 2,200 $\mathrm{kN}$ for DF12

At load of about 2,300 kN, the footing can no longer support additional load. Severe cracking throughout the bottom face region occurs.

\section{Use of Codes of Practice in Predicting the Failure Loads}

Generally, codes do not differentiate between punching shear strength of flat plates and footings, but it allows subtracting a part of the soil reaction from the punching load. However, this amount differs from one code to another according to the critical path location. In this study, no reaction is subtracted since this area, in some codes, are bigger than the footing itself.

According to the design code, the ultimate shear is:

$$
V_{u}=v_{c} b_{o} d
$$

where:

$v_{c}$ : Shear stress at punching of the control section,

$b_{o}$ : Perimeter of the control section according to adopted regulations, see Figure 9.

d: Effective depth of footing.

Describing the detailed procedure and recommendations of these codes are not within the scope of this paper.

The ultimate axial force shown in Table 4 was calculated for the purpose of comparison, and it was assumed that the safety reduction factors equal to one. 


\subsection{ACI 318-14 [1] Code}

The ACI code [7] takes the critical section at $(0.5 \mathrm{~d})$ from the column face and its shape similar to the column shape. The concrete punching shear capacity in the control section is calculated according to the equations (a), (b) and (c) listed in Table 22.6.5.2 of the ACI code.

\subsection{BS 8110-1:1997 [2] Code}

This code takes the critical section at a distance of $(1.5 \mathrm{~d})$ from the column face and its shape also similar to the column shape. In this work, the partial safety factor taken is $\gamma_{\mathrm{m}}=1.25$.

\subsection{Eurocode 2 [3] Code}

The punching shear capacity around the column is checked on two places, along the column perimeter and in the basic control section at the distance of $(2.0 \mathrm{~d})$ from the face of the column. The material resistance factor for concrete taken is $\gamma_{\mathrm{c}}=1.5, \sigma_{\mathrm{cp}}=1.5$, and $\beta=1.15$.

\section{Comparison between the FE Model and Literature Experimental Results}

The punching databank for footings without shear reinforcement contains 23 punching tests. The comparison between these tests and selected codes are based on the ratio of the punching load $\mathrm{V}_{\text {code }}$ and the experimental punching load $\mathrm{V}_{\text {test }}$. The punching shear capacities were calculated using characteristic concrete strength $\left(\mathrm{f}_{\mathrm{c}, \mathrm{cyl}}=\right.$ $\left.0.85 \times \mathrm{f}_{\mathrm{cu}}\right)$.

The results in Table 4 that obtained from literature experiments, the results based on this work, and codes are clearly shown in Figure 10.

\section{Conclusions and Recommendations}

The following conclusions can be stated based on the evaluation of the analyses of the reinforced concrete footing:

1. Modeling the punching shear failure of concrete footing by nonlinear finite element is adequate flexibility to solve complex problems as in realistic soil bedding.

2. The tests results when compared with the predicted strength obtained from ACI [1], BS [2], and Eurocode-2 [3] design equations and they showed underestimation of the footing strength by about 46 , 52 , and $52 \%$ respectively, while it was just $10 \%$ when compared with the FE results.

3. In the current study, the adopted criterion for obtaining the maximum punching shear failure load is when shear crack pattern in the incomplete punching pyramid under the column reach the top face of the footing followed by excessive deflection. By using this criterion, the predicted results converged well to the test results.

4. The fact that all the codes calculations give high (Exp/Calc) ratios indicates that the punching effect on footings is less pronounced when compared with an ordinary flat slab. Further work is recommended to confirm this inference.

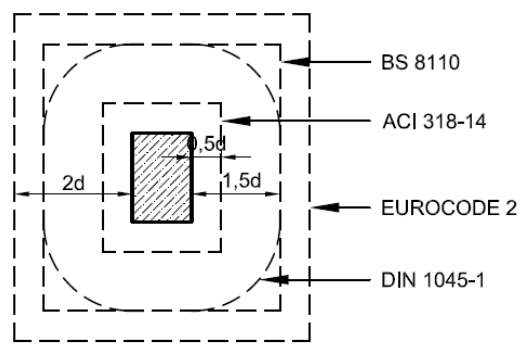

Figure 9. The critical punching perimeter section for different codes

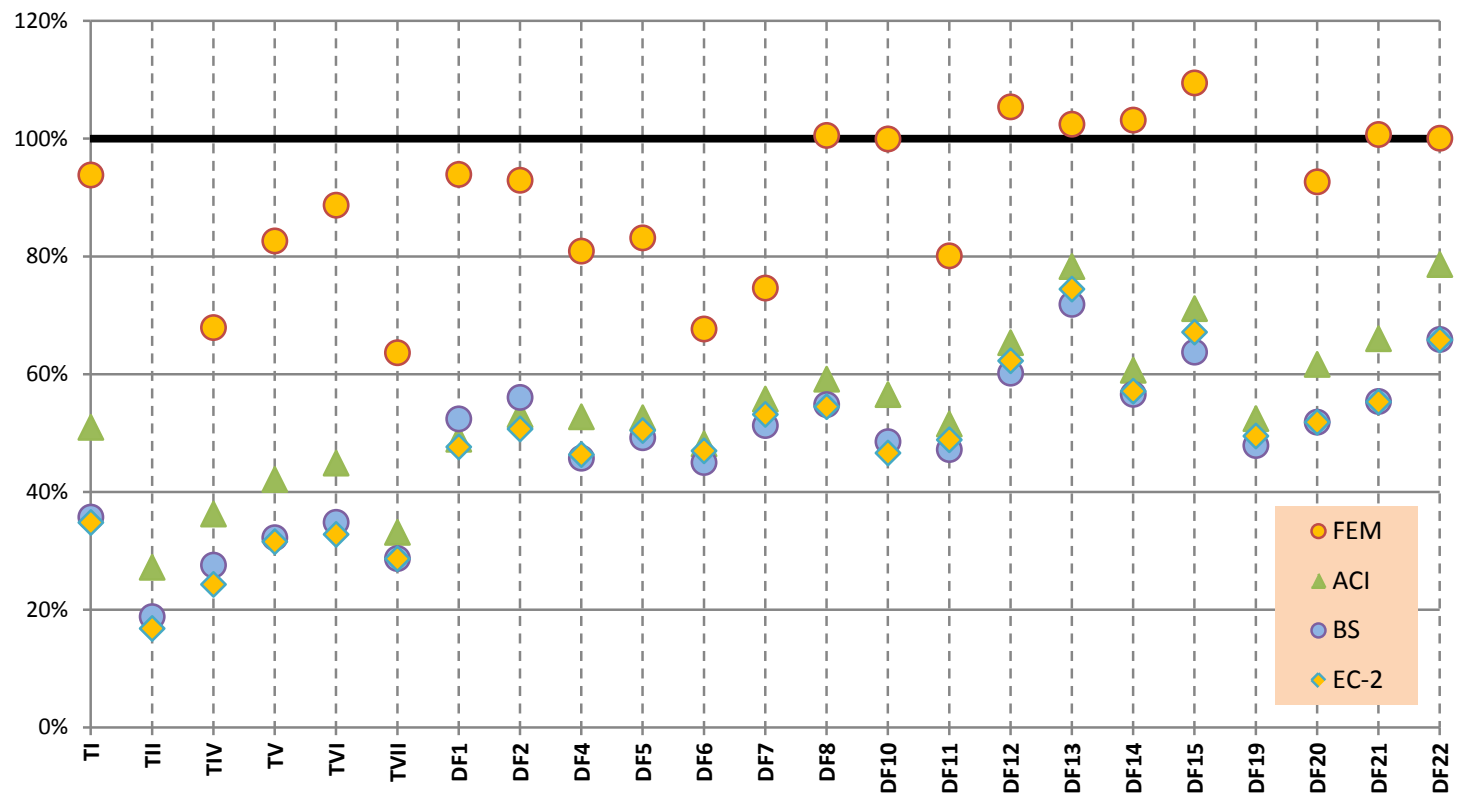

Figure 10. Comparative diagrams of ultimate force ratios calculated by FE and codes (the 100\% represents the experimental) 


\section{References}

[1] ACI Code 318M-14 (2015). "Building Code Requirements for Reinforced Concrete", American Concrete Institute.

[2] British Standards Institution BS8110 (1997). "Code of Practice for Design and Construction", British Standard Institution, Part 1, London.

[3] European Standard (2004). "Eurocode 2: Design of concrete structures - Part 1-1: General rules and rules for buildings", approved by CEN

[4] Folić, R., Bonić, Z. (2013). "Punching of column footings Comparison of Experimental and Calculation Results", GRAĐEVINAR 65 (10), pp. 887-899.

[5] Hallgren, M., Kinnunen, S. and Nylander, B. (1998). "Punching Shear Tests on Column Footings", Nordic Concrete Research 21(1), No. 1, Oslo, pp. 1-22.

[6] Hegger, J., Sherif, A.G., Ricker, M. (2006). "Experimental Investigations on Punching Behavior of Reinforced Concrete Footings", ACI Structural Journal, July-August, pp. 604-613.
[7] Hegger, J., Ricker, M., and Sherif, Alaa G. (2009). "Punching Strength of Reinforced Concrete Footings", ACI Structural Journal, V. 106, No. 5, pp. 706-716.

[8] Joseph E. Bowles (1974). "Analytical and Computer Methods in Foundation Engineering”, Book by McGraw-Hill Kogakusha.

[9] Lee, S., Moon, J., Park, K., and Bae K. (2014). "Strength of Footing with Punching Shear Preventers", Hindawi Publishing Corporation, Vol 2014, Article ID 474728, 15 pages.

[10] Rivkin, S. (1967). “Calculation of Foundations”, Budivel'nik (in Russian).

[11] Talbot, A.N. (1913). "Reinforced Concrete Wall Footings and Columns under Concentrated Loads", Research and Development Bulletin D47, Illinois.

[12] Timm, M. (2003). "Durchstanzen von Bodenplatten unter rotationssymmetrischer Belastung", $\mathrm{PhD}$ thesis, Technical University of Brunswick, Brunswick, Germany, pp. 159 (in German).

[13] Vacev, T., Bonić, Z., Prolović, V., Davidović, N., Lukić, D. (2015). "Testing and Finite Element Analysis of Reinforced Concrete Column Footings Failing by Punching Shear", Engineering Structures, Volume 92, PP. 1-14. 